\title{
Biochemical Compositions in the Follicular Fluid of Different Follicle Groups and Their Relationship with the Blood Concentrations in Dromedary Camels
}

\author{
M. A. M. M. Shehab-El-Deen ${ }^{1,2}$, S. N. Al-Dobaib ${ }^{1}, \&$ K. A. Al-Sobayil ${ }^{1}$ \\ ${ }^{1}$ Department of Animal Production and Breeding, College of Agriculture and Veterinary Medicine, Qassim \\ University, Buraidah, Saudi Arabia \\ ${ }^{2}$ Department of Animal Production, Faculty of Agriculture, Suez Canal University, Ismailia, Egypt \\ Correspondence: M. A. M. M. Shehab-El-Deen, Department of Animal Production and Breeding, College of \\ Agriculture and Veterinary Medicine, Qassim University, 51452 Buraidah, Saudi Arabia. Tel: 966-56-412-6411. \\ E-mail: m.shehabeldeen@qu.edu.sa
}

Received: September 10, 2019

Accepted: September 27, 2019

Online Published: September 30, 2019

doi:10.5539/ijb.v1 $1 \mathrm{n} 4 \mathrm{p} 112$

URL: https://doi.org/10.5539/ijb.v11n4p112

\begin{abstract}
Metabolic profile changes of the follicular fluid of the growing follicles can be used as an indirect indicator of the oocyte and granulosa cells quality. The aim of this study was to investigate the biochemical compositions of follicular fluid collected from follicles at different stages of growth and their relationship with that of blood serum in Dromedary camel. Ovaries were colleceted from local slaughterhouse (Oniza, KSA). Soon after slaughtering, blood samples were collected from Dromedary camel $(n=20)$ and follicular fluid was aspirated from three different groups of non-atretic follicles (4-6) $\mathrm{mm}, 6-8 \mathrm{~mm}$ and $10-20 \mathrm{~mm}$ diameter). Follicular samples were pooled by maintaining the follicular sizes. Concentrations of glucose, cholesterol, triglycerides, urea, total protein, lactate dehydrosenase (LDH), cortisol, triiodothyronine (T3), insulin-like growth factor-1 (IGF-1) and non-esterified fatty acids (NEFA) were assayed in each serum and follicular fluid sample. The concentrations of glucose, cholesterol, triglycerides, total protein, LDH, T3, IGF-1 and NEFA decreased in the follicular fluid irrespective of follicular sizes and increasing in trend for urea in comparison with blood serum. There was a significant concentration gradient for IGF-1 in small follicular group compared to large or medium groups. Our data from the present study suggest that the oocyte and the granulosa cells of Dromedary she camel develop in a biochemical environment that does not have remarkable changes from small to large follicles except for IGF-1. In conclusion, the above-mentioned metabolic changes in the growing follicle is related to blood metabolic changes and, therefore, may be used in determining follicular dominance, oocyte and granulosa cells quality in Dromedary camel.
\end{abstract}

Keywords: Camel Ovary, Follicular Sizes, Blood Metabolites, Follicular Fluid Composition

\section{Introduction}

Camel is one of the most significant species of livestock, particularly in the Middle East and Southern Asia Because of the harsh and dry environment in the Arabic regions, cattle cannot yield its expected milk and meat. In this context, Arabian camel is found better for producing milk and meat in comparison with cattle in the harsh environment. Moreover, camel race in the Middle East makes an extra recreational value to the people. Depressed camel reproductive performance, however, is regarded as one of the major limiting factors (Mukasa-Mugerwa, 1981; Elwishy, 1987). The low reproductive performance in camelids is due to its characteristic ovulation pattern commonly termed as induced ovulator. Moreover, camel is a seasonal breeder which means both male and female come into heat during breeding season. Particularly, the advanced age of puberty (3-4 years) and therefor longer age at first calving, the comparatively brief breeding season, the lengthy gestation period of 13 months and late postpartum estrus. For instance, the overall calving rate was approximately $40 \%$ with a mortality rate of $17 \%$ between birth and one year of age (Djellouli \& Saint-Martin, 1992).

Because camelids are induced-ovulator, ovarian follicles tend to regress after certain initial phase of development if mating does not occure (Adams et al., 1990; Skidmore et al., 1995). This is because mating induces the secretion of $\mathrm{LH}$, which results in ovulation. However, the stage of the cycle was very important for being ovulation after 
mating or treating with LH. Skidmore et al. (1996) reported that an ovulation rate of around $80 \%$ could be achieved when the dominant follicle measured between $1.0-1.9 \mathrm{~cm}$ in diameter, but the ovulation rate dramatically reduced to $<20 \%$ if the follicle measured between $2.0-2.9 \mathrm{~cm}$ and no follicles $>3.0 \mathrm{~cm}$ ovulated in response to mating or $\mathrm{LH}$ treatments. In bovine, the decrease in fertility in high-yielding dairy cows is primarily an issue of poor oocyte and embryo quality, rather than a disturbance of gonadotropin secretion (O'Callaghan \& Boland, 1999). Follicles contain follicular fluid which possesses a large stockpile of mRNA, protein, enzymes and hormones (Leyens et al., 2004). The follicular fluid constitutes the biochemical environment needed to mature and protect oocytes until ovulation (Gosden et al., 1988; Józwik et al., 2001). In fact, the follicular fluid is partly an exudate of serum and is partially composed of locally produced substances, which are related to the metabolic activity of follicular cells (Gérard et al., 2002).

In dairy cows, changes in concentrations of GnRHs, steroid hormones and growth factors in ovarian follicles have been connected with inferior oocyte quality (Izadyar et al., 1997; Driancourt \& Thuel, 1998). Furthermore, the metabolites such as glucose, $\beta$-hydroxybutyrate $(\beta-\mathrm{OHB})$, lactate, urea, total protein, triglycerides, non-esterified fatty acids (NEFA) present in the follicular fluid have also been found liked with oocyte quality (Leroy et al., 2004). The authors also reported that the changes in metabolites were associated with size of the follicles i.e. glucose, $\beta$-OHB and total cholesterol increased from small to large follicles. Remarkably, the same research group found a strong correlation with metabolites between blood and follicular fluid. This is because metabolites change considerably in the follicular environment during the follicle's development stage (Wise, 1987; Gosden et al., 1988). The follicular development can better be predicted by using ultrasonographic technique (David et al., 2005).

However, measuring of the follicular development with ultrasonography requires high skills and especially in camel it seems more difficult compared to dairy cows. Considering the limitations for ultrasonography in camel, it would be highly beneficial if we could make a correlation of follicular development with blood metabolites. The objectives of this research were therefore to determine the biochemical compositions of follicular fluid in three different follicle sizes and finally to compare and correlate the biochemical compositions of blood serum. Because of their importance in reproduction and fertility of dromedary camel, concentrations of glucose, cholesterol, triglycerides, urea, total protein, cortisol, T3, LDH, IGF-1 and NEFA were investigated in details.

\section{Materials and Methods}

\subsection{Animals, Ovary Collection and Sample Preparation}

Twenty adult she camel (dromedary) were used for this study. The animals were in good health and with normal reproductive tracts upon gross examination after slaughter. A blood sample was taken into three tubes (unheparinized, gel-clot activator tube; EDTA tube; sodium fluoride (NaF) tube) (Xinle Medical ${ }^{\circledR}, \mathrm{KSA}$ ) during slaughter and both ovaries were collected after slaughter. Both ovaries and the blood samples for the same animal were labeled and cooled $\left(4^{\circ} \mathrm{C}\right)$. Blood sample was allowed to coagulate for $20 \mathrm{~min}$ at $15^{\circ} \mathrm{C}$ and then cooled at $4^{\circ} \mathrm{C}$, after which the ovaries and blood samples were transported on ice $\left(4^{\circ} \mathrm{C}\right)$ to the laboratory. At laboratory, ovaries were washed twice in warmed $0.9 \% \mathrm{NaCl}$ and blotted dry. Three different follicle classes, based on follicle diameter, were considered for puncture: small follicles $(4-6 \mathrm{~mm})$, medium follicles $(7-9 \mathrm{~mm})$ and large follicles $(10-20 \mathrm{~mm})$. Follicular fluid was aspirated by a $21 \mathrm{G}$ needle attached to $5 \mathrm{ml}$ syringe and pooled per follicle size within the same camel. For each camel and follicle group, a different syringe and needle were used. Follicular fluid was centrifuged $(10,000 \times g$ for $10 \mathrm{~min})$ and the supernatant was collected for analysis. The coagulated and other blood samples were centrifuged $(1400 \times \mathrm{g}, 30 \mathrm{~min})$ within $2 \mathrm{~h}$ from collection and the serum or plasma were harvested. Sample preparation was finished during $3 \mathrm{~h}$ from slaughter. All follicular fluid, sera and plasma samples were stored at $-20^{\circ} \mathrm{C}$ until biochemical assay.

\subsection{Biochemical Analyses}

In each sample, the concentrations of, glucose, cholesterol, triglycerides, urea, total protein, LHD and NEFA were measured. All analyses were performed at the Department of Animal Production and Breeding, Qassim University, Saudi Arabia. The metabolite concentrations in follicular fluid and blood serum were performed with Autoanalyser (random-access analyzer; Humastar 100). All measurements were carried out according to the manufacturers' instructions. Triiodothyronine (T3), cortisol (Human Diagnostics, KSA) and IGF1 (BioSource Europe S.A.) hormones were measured using specific enzyme-linked immunosorbent assay (ELISA) kits. The measurement was carried out according to the manufacturer's instructions. 


\subsection{Statistical Analyses}

The overall mean concentration \pm S.E.M. of each metabolite was calculated for follicular fluid and for blood in all she camel. The concentrations of each factor in the follicular fluid were compared among the three follicle groups. A comparison was made for the levels in the follicular fluid of each follicle group and those of blood. Data of blood and follicular fluid groups were subjected to one-way ANOVA using JMP Ver. 11 (SAS, 2013) in which the she camel is considered as a random effect. The significance of difference among the blood and follicular fluid group was assessed using Duncan's new multiple range test. Significance was set as $P<0.05$. Correlation coefficient was computed between follicle groups and blood serum using PROC CORR procedure.

\section{Results}

The results of different metabolites are shown in Figures 1, 2, 3, 4, 5, 6, 7, 8, 9 and 10. The concentrations of Triiodothyronine, glucose, cholesterol, triglyceride, total protein, LDH, IGF1 and NEFA decreased in follicular fluid irrespective of follicular sizes as compared to blood serum $(P<0.05)$. In contrast, urea had an opposite pattern where there was an increasing in tendency of concentration in different follicular sizes in comparison with blood serum. Interestingly, the concentration of various metabolites among the different follicular sizes did not differ significantly except in the case of cortisol and IGF1. Although the concentration of IGF1 between the largeand medium-sized follicles did not differ significantly, the small-sized follicle had lower amount of IGF1 (95.34, 95.14 and $84.43 \mathrm{ng} / \mathrm{mL}$, respectively). Furthermore, though the amount of cortisol among the follicles did not differ but medium-sized follicle had of almost half of them $(4.01,4.18$ and $2.06 \mu \mathrm{g} / \mathrm{dL}$, respectively). Furthermore, correlation analysis showed that glucose $(r \geqslant 0.69 ; \mathrm{P}<0.05)$, NEFA $(r \geqslant 0.9 ; \mathrm{P}<0.01), \mathrm{T} 3(\mathrm{r} \geqslant 0.76 ; \mathrm{P}<0.05)$ and urea $(r \geqslant 0.73 ; \mathrm{P}<0.05)$ levels in the growing follicles were correlated with blood metabolites.

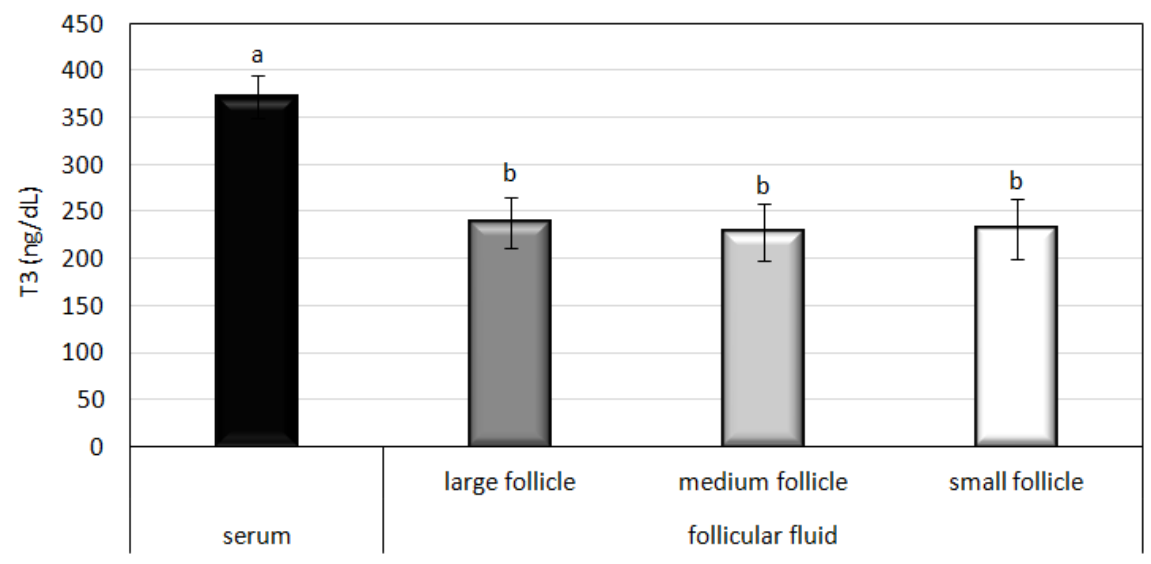

Figure 1. Concentrations of Triiodothyronine (T3; ng/dL) in blood serum and follicular fluid from different follicle groups

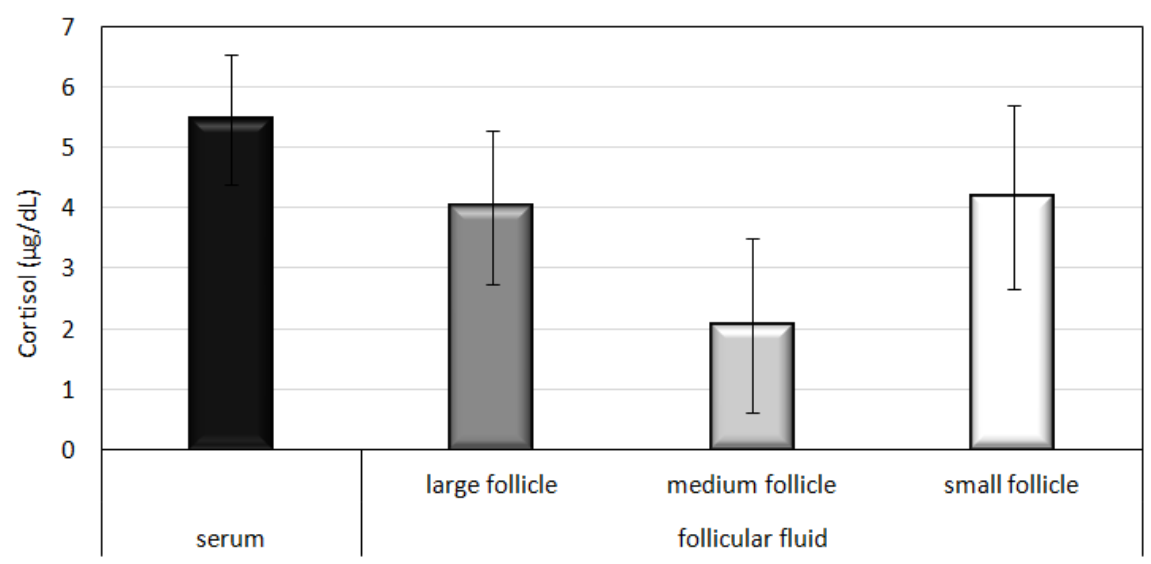

Figure 2. Concentrations of cortisol $(\mu \mathrm{g} / \mathrm{dL})$ in blood serum and follicular fluid from different follicle groups 


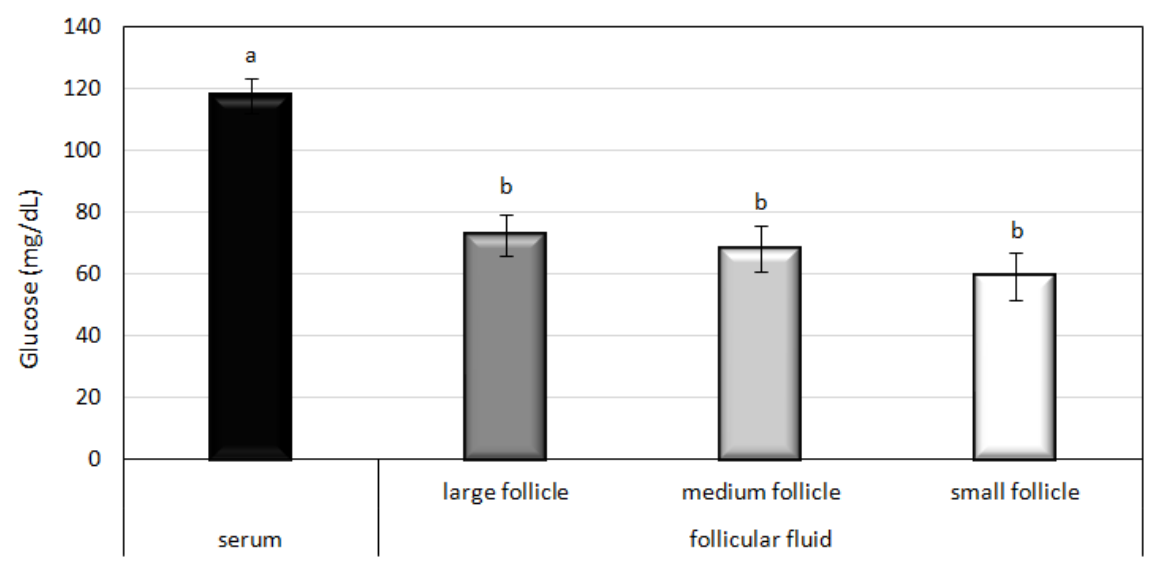

Figure 3. Concentrations of glucose $(\mathrm{mg} / \mathrm{dL})$ in blood serum and follicular fluid from different follicle groups

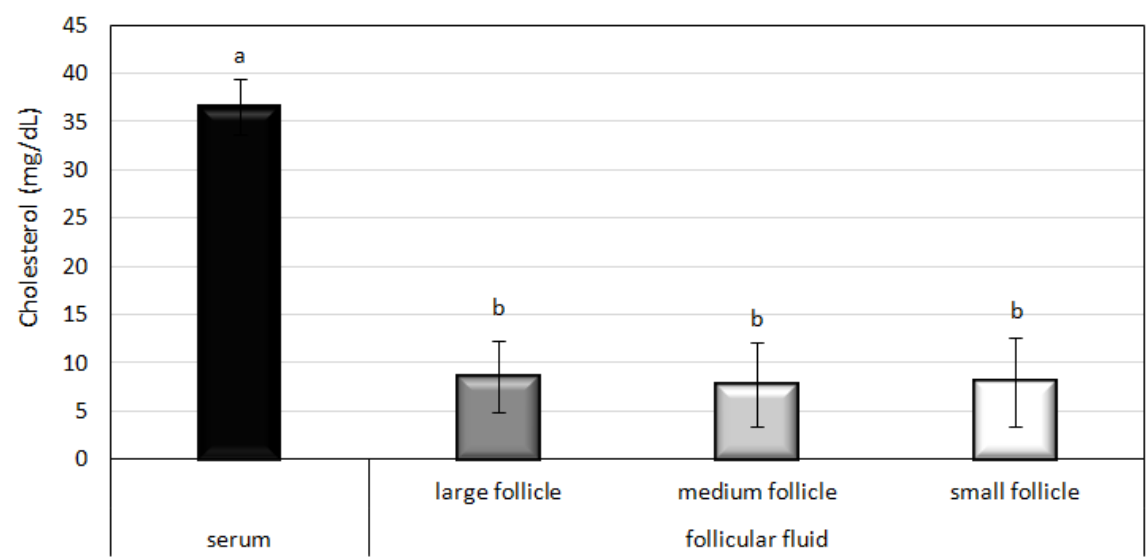

Figure 4. Concentrations of cholesterol $(\mathrm{mg} / \mathrm{dL})$ in blood serum and follicular fluid from different follicle groups

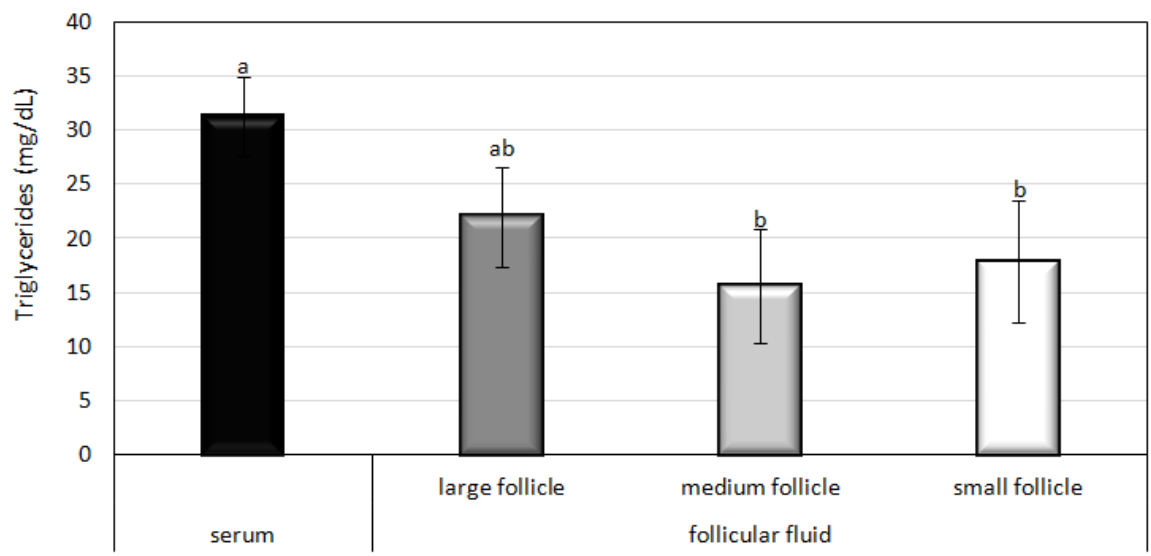

Figure 5. Concentrations of triglycerides $(\mathrm{mg} / \mathrm{dL})$ in blood serum and follicular fluid from different follicle groups 


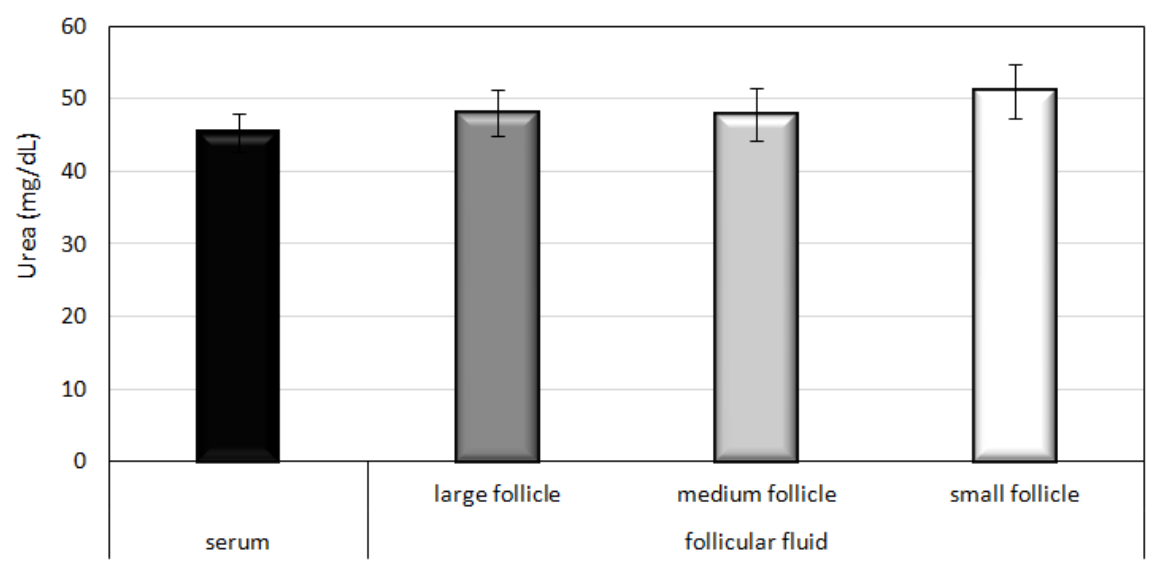

Figure 6. Concentrations of urea $(\mathrm{mg} / \mathrm{dL})$ in blood serum and follicular fluid from different follicle groups

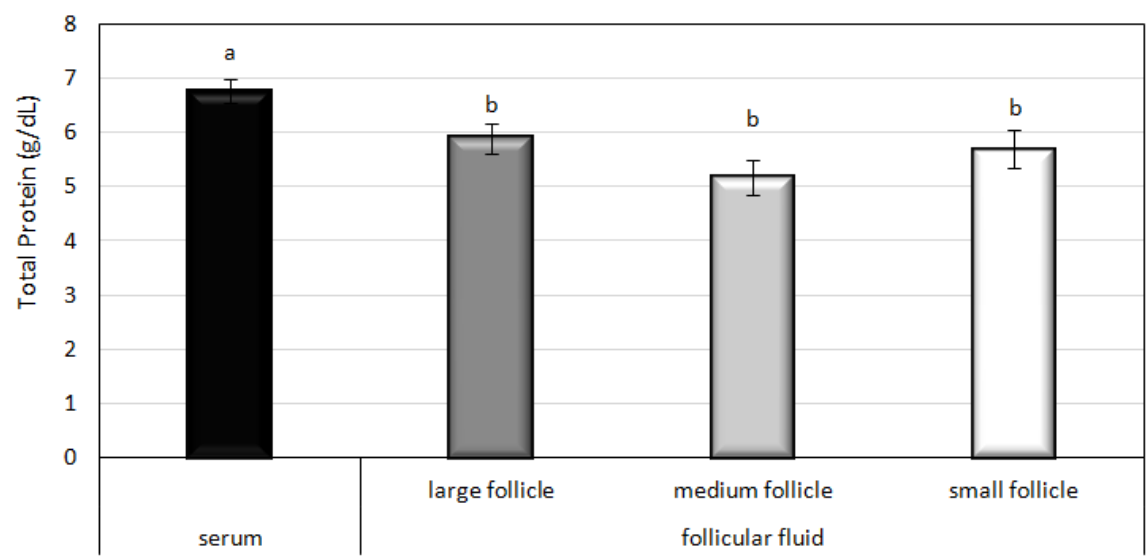

Figure 7. Concentrations of total protein $(\mathrm{g} / \mathrm{dL})$ in blood serum and follicular fluid from different follicle groups

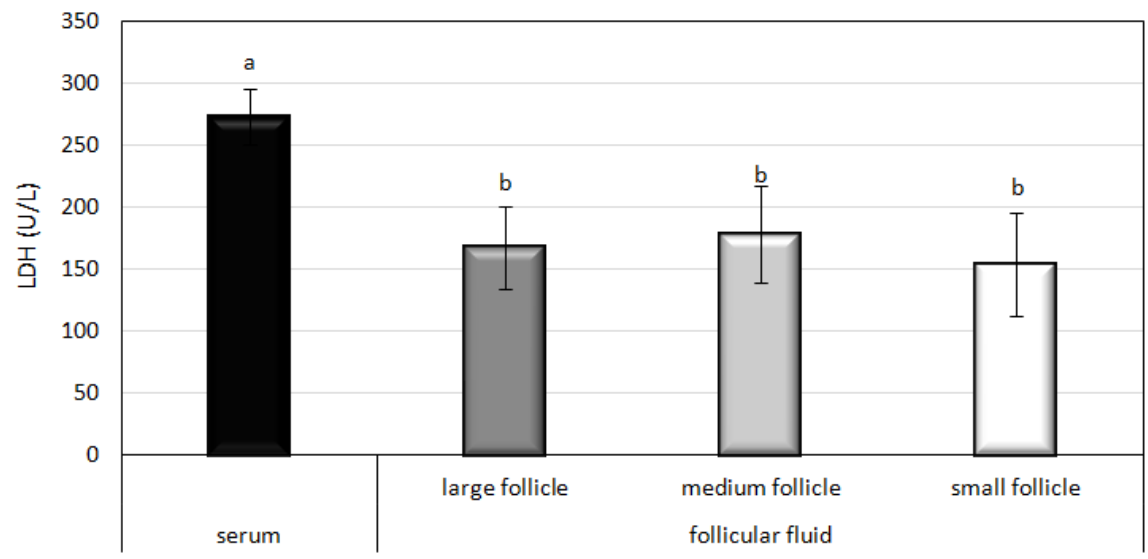

Figure 8. Concentrations of LDH (U/L) in blood serum and follicular fluid from different follicle groups 


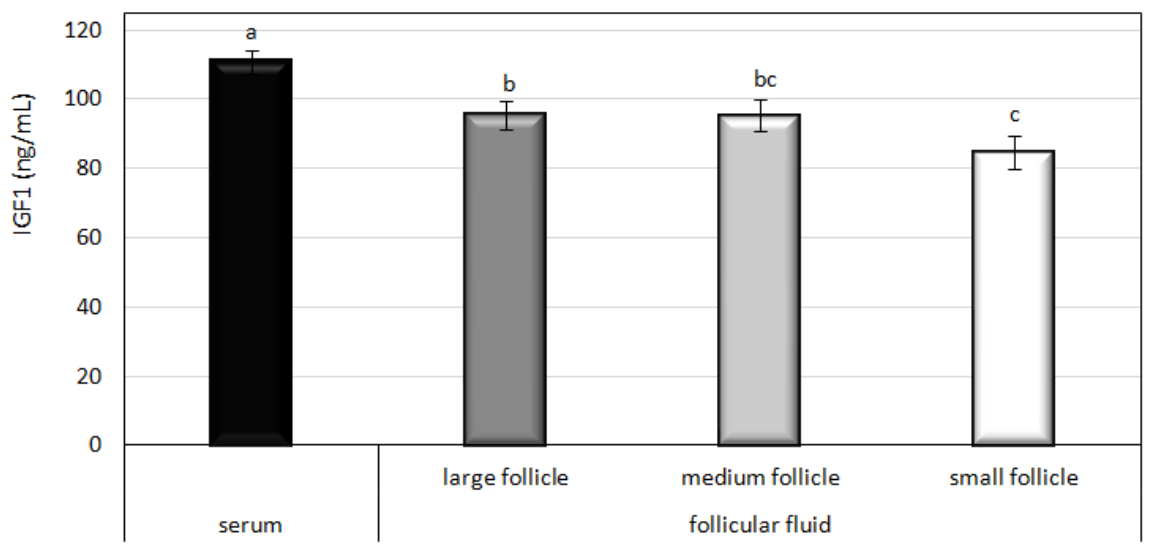

Figure 9. Concentrations of IGF-1 (ng/mL) in blood serum and follicular fluid from different follicle groups

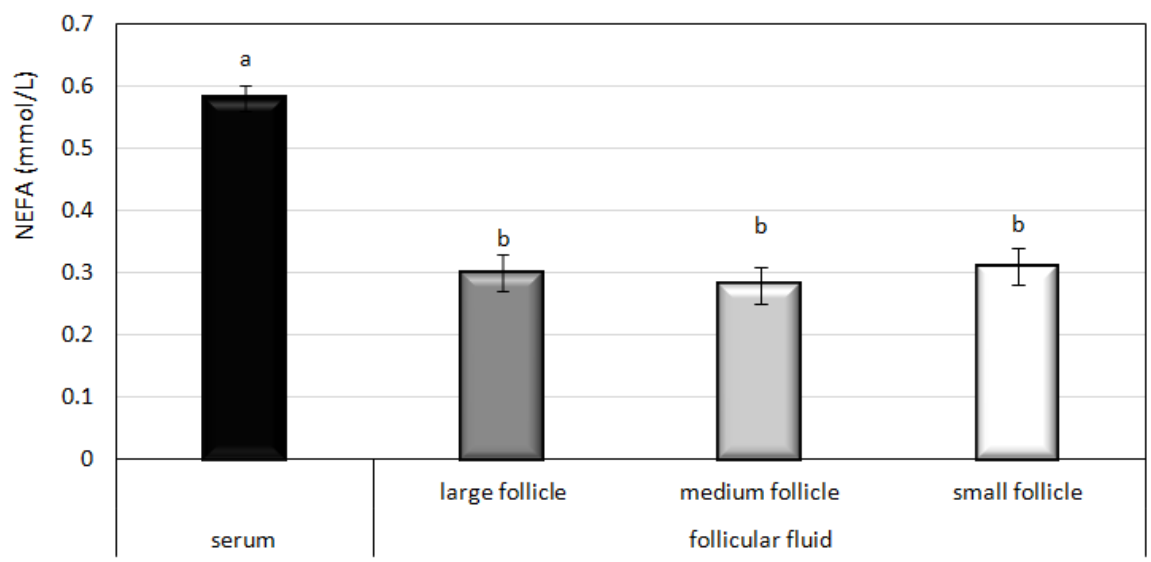

Figure 10. Concentrations of NEFAs $(\mathrm{mmol} / \mathrm{L})$ in blood serum and follicular fluid from different follicle groups

\section{Discussion}

Like the previous studies in cows (Wise, 1987; Hammon et al., 2000), Samples of follicular fluid from different she camels were collected and pooled together. We did not collect fluid from atretic follicles as of other studies in cows (Homa \& Brown, 1992, Leroy et al., 2004) since around $85 \%$ of all antral follicles show signs of atresia. However, we cannot completely roll-out the possibility of having a percentage of follicles sampled were atretic in all follicle groups (Kruip \& Dieleman, 1982). However, in current study we did not collect the follicular fluid from the follicles larger than $20 \mathrm{~mm}$ to avoid the possibility of harvesting FF from atretic follicles, hence, in most of she-camels the follicles begin to regress when reach $20 \mathrm{~mm}$ in diameter (Skidmore et al., 1996).

Glucose is the major source of energy in ovarian metabolism. It is metabolized in the ovary through anaerobic pathway, leading to formation of lactate (Boland et al., 1994; Rabiee et al., 1997, 1999). In our study, we observed that glucose concentration in follicular fluid was lower in all follicular sizes than those measured in blood serum, indicating ovary is one of the main sites for glucose metabolism in camel. Hassan et al., (2018) stated that large follicles had more glucose concentration than small follicle which is in agreement of our findings. In contrast to our study, Leroy et al. (2004) showed in cows that the glucose concentration increases with the pace of increasing the follicle diameter. This may explain the more intense glucose metabolism in camel follicles, resulting in a higher consumption of glucose from follicular fluid and possibly a decreased lactate secretion. The increasing quantity of follicular fluid is a second explanation for the reduction in glucose and the rise in lactate, as follicles have a comparatively large number of granulosa cells which use glucose and secrete lactate into the follicular fluid in a comparatively bigger quantity. (McNatty et al., 1978; Gosden et al., 1988). In cows, the lager amount of glucose in the follicular fluid is considered to be associated with the increased permeability of the blood-follicle barrier during follicular growth (Okuda et al., 1982; Bagavandoss et al., 1983) and possibly different in camel that 
warrants for studies. In women, the concentrations of glucose and lactate in follicular fluid consequence from both glycolysis and influx of the same plasma molecules into the fluid. (Leese \& Lenton, 1990). Our data also suggest that hypoglycemia may decrease the concentration of glucose in follicular fluid, but this must be verified by more research in hypoglycemic she camel. Another likely consideration would be the postmortem changes that can lead to increased levels of potassium through leakage from damaged cells and turnover of glucose to lactate through anaerobic glycolysis (Gosden et al., 1988). Pregnancy status is also proven to affect the concentration of glucose in follicular fluid, as, El-Shahat et al., (2013) found that glucose concentrations were greater in the large ovarian follicles in non-pregnant she-camels than in the same follicle size in pregnant camels.

The concentrations of triglycerides in the follicular fluid of all sizes were lower than the blood serum. However, the concentrations of triglycerides did not significantly differ in the follicular fluid of different follicle classes. The concentrations of triglyceride in follicular fuid harvested from medium and small groups were significantly lower than in blood serum. The triglyceride in large follicles did not differe from blood serum. It appears that only in large follicles there is a significant correlation between follicular fluid and serum in triglyceride concentrations. These information support the idea that follicular triglyceride is primarily caused by local metabolic processes. (Leroy et al., 2004). According to Wehrman et al. (1991), the ovarian follicle of cows maintains a fairly stable concentration of triglycerides, regardless of how much blood serum increases due to physiological status or diet. Research shows that triglycerides cannot pass through the follicular membrane because it is predominantly transported along with the very low-density lipoprotein (VLDL) that is too big to transfer through the follicular membrane barrier (Grummer \& Carroll, 1988). It is possible that triglycerides in the follicular fluid may serve as an alternative energy source since cells cultured in vitro can absorb and use triglycerides from the culture medium. Furthermore, oocytes show lipid accumulation when cultured in vitro in the medium containing triglycerides (Kim et al., 2001, Abe et al., 2002).

The concentrations NEFA follow the levels of triglycerides (Abe et al., 2002). This is in fact NEFA is transported into the blood by making a complex with albumin that can easily enter into the follicular fluid by penetrating the follicular wall. NEFA concentrations did not differ among the different follicular sizes compared to blood serum. This is indicating a high correlation of NEFA levels in the follicular fluid with blood serum levels but cannot be used as different follicular classes. High concentrations of NEFA have a direct toxic effect on the ovaries (Britt, 1992; Kruip \& Kemp, 1999), and more specifically on oocyte developmental competence, and also on granulosa cells (Leroy et al., 2005). In our study, low level of NEFA in the follicular fluid of all follicle classes is an indication of non-toxic follicular environment.

The increasing trend of urea levels at all follicular sizes was not expected. Although the concentration of urea at different sizes of follicles was not significantly higher than the serum level, the increasing trend explains the possible of cause of an active inward transport or a local urea production by the follicle cells. In mares, Collins et al. (1997) found a very high correlation of urea between blood serum and follicular fluid. In cows, Leroy et al. (2004) also reported a high correlation between follicular fluid and blood serum for urea. The authors further reported that the effects of increased urea levels on fertility are contradictory. There was an agreement on the possible adverse effect of diet-induced elevated urea levels that might act at the level of the oocyte (Sinclair et al., 2000; Dawuda et al., 2002). The increasing of trend of urea levels at different follicular sizes as compared to blood serum suggests that elevated serum urea levels of she camels may be reflected in the follicular fluid and hence, may have negative influence on oocyte quality which requires further in-depth investigation.

The total protein content in the follicular fluid was significantly lower among different follicle classes, and was about $87 \%$ of that present in blood serum. The high correlation between total protein content in the follicular fluid and in the blood serum suggests that a considerable amount of the protein content in the follicular fluid originates from blood serum (Edwards, 1974; Wise, 1987). The lactate dehydrogenase (LDH) enzyme is widely distributed in tissue particularly in the heart, liver, muscles and kidneys. Elevated serum levels of LDH have been observed in a variety of disease states. In the present study, we wanted to make a correlation of LHD concentration between follicular fluid and blood serum. According to our expectation, we observed significantly less concentration of LDH in follicular fluid indicating the animals are free from diseases at least in part reproductive diseases. A slight decrease in LDH activity has also been reported in pregnant camels (Khadjeh, 2002; Saeed et al., 2009). However, in buffalo cows, a decrease in LDH activity prior to the parturition was observed (Prabhakar et al., 1999).

Insulin-like growth factor-1 (IGF1) is well known to exert a protective role against the incidence of spontaneous apoptosis in both oocyte and embryo by decreasing the effect of oxidant (Jousan \& Hansen, 2004). Inferior follicle quality has been found with a result of low intra-ovarian factors such as IGF-1 (Richards et al., 1995; Hamilton et al., 1999). Moreover, the altered metabolic conditions in the follicular fluid were directly related to the low level of 
IGF1 in cows (Shehab-El-Deen et al., 2010). In our study, we observed significantly low level of IGF1 in the follicular fluid collected from small follicles, indicating the oocytes originated from small follicles are of less competent. Interestingly, as follicle diameter increases the IGF1 concentration in the follicular fluid increases that may be determining the follicular dominance as the follicle in early growth phase effected by the bioavailability of IGF1 (Armstrong et al., 2002). As such, the concentrations of the free IGF1 in the growing follicle might determine follicle fate. This may be explained by the results of El-Bahr et al., (2015) who demonstrated that IGF1 concentrations in medium to large follicles were found to be comparable to IGF1 serum concentration. Furthermore, IGF1 supports FSH and allows the future dominant follicle to quickly upregulate estradiol production and hence to suppress circulating FSH and prevent the subordinate follicles from further growth (Fortune et al., 2004).

The secretion from adrenal gland, mainly cortisol elicits physiological adjustment that enables animal to tolerate stressful conditions. In agreement Endo et al., (2017) reported that hair cortisol level at 60 to 90 days after parturition in Holstein cows increased significantly in the dry period. In an in vitro study, Santana et al. (2016) showed that the blastocysts developed from oocytes matured in cortisol-supplemented medium expressed higher relative levels of glucose transporter 1 (GLUT1), fatty acid synthase (FASN), and heat shock protein 70 (HSP70). This study indicates a positive role of cortisol in the acquisition of bovine oocyte competence which is evidenced by increased blastocyst development rates with elevated embryonic transcripts. This in fact may play a role in glucose and lipid metabolism, as well as the cellular response to stress. Our study data are in line where the cortisol level between blood serum and follicular fluid did not differ significantly, indicating the development of competent oocytes. However, cortisol in medium-sized follicles was lower in trend, indicating lower developmental capacity of oocytes which needs to be studied further. Although the role of Triiodothyronine (T3) in camel reproduction is very scares, the supplementation of $\mathrm{T} 3$ in bovine in vitro maturation medium has been found beneficial on the kinetics of embryo development (Costa et al., 2013). In a very recent study, Singh et al. (2017) also reported that supplementation of T3 in bovine culture medium increased embryo cleavage rate. In our study, we observed significantly lower level of $\mathrm{T} 3$ in all follicle classes compared to blood serum, indicating no visible effect on oocyte development which needs to be studied further.

\section{Conclusions}

In conclusion, we observed a decrease in the concentrations of glucose, cholesterol, triglycerides, total protein, T3, LHD, IGF1 and NEFA and an increasing trend of urea in the follicular fluid. Although we have observed a little variation in the concentrations of the metabolites, however, no significant differences were observed among different follicle classes. Our data suggest that the oocyte of camel grow and mature in a biochemical environment and that this environment is highly correlated with serum levels of the metabolites studied here. Further research should concentrate on changes in ions in the follicular fluid of different follicle classes and their effect on oocyte quality.

\section{Acknowledgements}

This research was funded by National Science, Technology and Innovation Plan (MAARIFAH) (research project no. 12-AGR3207-09), King Abdulaziz City for Science and Technology, Kingdom of Saudi Arabia. The authors are also grateful to the Deanship of Scientific Research, Qassim University.

\section{Conflict of interests}

The authors declare that there is no conflict of interests regarding the publication of this paper.

\section{References}

Abe, H., Yamashita, S., Satoh, T., \& Hoshi, H. (2002). Accumulation of cytoplasmatic lipid droplets in bovine embryos and cryotolerance of embryos developed in different culture systems using serum-free or serum-containing media. Molecular Reproduction \& Development, 61, 57-66.

Adams, G. P., Sumar, J., \& Ginther, O. J. (1990). Effects of lactational and reproductive status on follicular waves in llamas. Journal of Reproduction Fertility, 90, 535-545.

Armstrong, D. G., Baxter, G., Hogg, C. O., \& Woad, K. J. (2002). Insulin-like growth factor (IGF) system in the oocyte and somatic cells of bovine preantral follicles. Reproduction, 123(6), 789-797.

Bagavandoss, P., Midgley, A. R., \& Wicha, M. (1983). Developmental changes in the ovarian follicular basal lamina detected by immunofluorescence and electron microscopy. Journal of Histochemistry Cytochemistry, 31, 633-640. 
Boland, N. I., Humpherson, P. G., Leese, H. J., \& Gosden, R. G. (1994). The effect of glucose metabolism on murine follicle development and steroidogenesis in vitro. Human Reproduction, 9, 617-623.

Britt, J. H. (1992). Impacts of early postpartum metabolism on follicular development and fertility. In Proceedings of the 24th Annual Convention-American Association of Bovine Practitioners (pp. 39-43).

Chang, S. C. S., Jones, J. D., Ellefson, R. D., \& Ryan, R. J. (1976). The porcine ovarian follicle. I. Selected chemical analysis of follicular fluid at different developmental stages. Biology Reproduction, 15, 321-328.

Collins, A., Palmer, E., Bezard, J., Burke, J., Duchamp, G., \& Buckley, J. A. (1997). A comparison of the biochemical composition of equine follicular fluid and serum at four different stages of the follicular cycle. Equine Veterinary Journal (Suppl), 25, 12-16.

Correa-Calderon, A., Armstrong, D., Ray, D., DeNise, S., Enns, M., \& Howison, C. (2004). Thermoregulatory responses of Holstein and Brown Swiss Heat-Stressed dairy cows to two different cooling systems. International Journal of Biometeorology, 48(3), 142-148.

Costa, N. N., Brito, K. N. L., Santana, P. P. B., Cordeiro, M. S., Silva, T. V. G., Santos, A. X., Ramos, P. C., Santos, S. S. D., King, W. A., Miranda, M. S., \& Ohashi, O. M. (2016). Effect of cortisol on bovine oocyte maturation and embryo development in vitro. Theriogenology, 85(2), 323-329.

Costa, N. N., Cordeiro, M. S., Silva, T. V. G., Sastre, D., Santana, P. P. B., Sá, A. L. A, Sampaio, R. V., Santos, S. S. D., Adona, P. R., Miranda, M. S., \& Ohashi, O. M. (2013). Effect of triiodothyronine on developmental competence of bovine oocytes. Theriogenology, 80(4), 295-301.

David, S. B., Fermin, J. K., Janet, L. H. I., Phil, G. K., \& James, J. I. (2005). Numbers of antral follicles during follicular waves in cattle: Evidence for high variation among animals, very high repeatability in individuals, and an inverse association with serum follicle-stimulating hormone concentrations. Biology of Reproduction, 73, 54-62.

Dawuda, P. M., Scaramuzzi, R. J., Leese, H. J., Hall, C. J., Peters, A. R., Drew, S. B., \& Wathes, D. C. (2002). Effect of timing of urea feeding on the yield and quality of embryos in lactating dairy cows. Theriogenology, 58, 1443-1455.

Djellouli, M., \& Saint-Martin, G. (1992). Productivity and economy of camel breeding in Tunisia. In W. R. Allen, A. J. Higgins, I. G. Mayhew, D. H. Snow, \& J. F. Wade (Eds.), Proceedings of the 1st International Camel Conference (pp. 209-212). Newmarket, UK: R\&W Publications.

Driancourt, M. A., \& Thuel, B. (1998). Control of oocyte growth and maturation by follicular cells and molecules present in follicular fluid. A review, Reproduction Nutrition Development, 38, 345-362.

Edwards, R. G. (1974). Follicular fluid. Journal of Reproduction and Fertility, 37, 189-219.

El-Bahr, S. M., Ghoneim, I. M., \& Waheed, M. M. (2015). Biochemical and hormonal analysis of follicular fluid and serum of female dromedary camels (Camelus dromedarius) with different sized ovarian follicles. Animal Reproduction Science, (159), 98-103.

El-Shahat, K. H., Abo-El Maaty, A. M., \& Moawad, A. R. (2013). Follicular fluid composition in relation to follicular size in pregnant and non-pregnant dromedary camels (Camelus dromedaries). Animal reproduction, 10(1), 16-23.

Elwishy, A. B. (1987). Reproduction in the female dromedary (Camelus dromedarius): A review. Animal Reproduction Science 15, 273-297

Endo, N., Kuroki, R., \& Tanaka, T. (2017). Comparison of productive and reproductive performance and hair cortisol levels between Brown Swiss cross-bred and Holstein cows housed in the same barn. Animal Science Journal, 88, 1506-1512.

Fortune, J. E., Rivera, G. M., \& Yang, M. Y. (2004) Follicular development: the role of the follicular microenvironment in selection of the dominant follicle. Animal Reproduction Science, 82-83, 109-126.

Gérard, N., Loiseau, S., Duchamp, G., \& Seguin, F. (2002). Analysis of the variations of follicular fluid composition during follicular growth and maturation in the mare using proton nuclear magnetic resonance (1HNMR). Reproduction, 124, 241-248.

Gosden, R. G., Hunter, R. H. F., Telfer, E., Torrance, C., \& Brown, N. (1988). Physiological factors underlying the formation of ovarian follicular fluid. Journal Reproduction and Fertility, 82, 813-825. 
Grummer, R. R., \& Carroll, D. J. (1988). A review of lipoprotein cholesterol metabolism: importance to ovarian function. Journal Animal Science, 66, 3160-3173.

Hamilton, T. D., Vizcarra, J. A., Wettemann, R. P., Keefer, B. E., \& Spicer, L. J. (1999). Ovarian function in nutritionally induced anoestrus cows: effect of exogenous gonadotrophin-releasing hormone in vivo and effect of insulin and insulin-like growth factor I in vitro. Journal of Reproduction and Fertility, 117, 179-187.

Hammon, D. S., Wang, S., \& Holyoak, G. R. (2000). Ammonia concentration in bovine follicular fluid and its effect during in vitro maturation on subsequent embryo development. Animal Reproduction Science, 58, $1-8$.

Hassan, M. S., Al-Nuaimi, A. J., Al-Yasari, M. A., \& Jameel, Y. J. (2018). Study the Effects of Follicular Size on some Biochemical Follicular Fluid Composition in She Camel (Camelus Dromedarius). Advances in Animal and Veterinary Sciences, (6), 341-346.

Homa, S. T., \& Brown, C. A. (1992). Changes in linoleic acid during follicular development and inhibition of spontaneous breakdown of germinal vesicles in cumulus-free bovine oocytes. Journal of Reproduction and Fertility, 94, 153-160.

Izadyar, F., Van Tol, H. T., Colenbrander, B., \& Bevers, M. M. (1997). Stimulatory effect of growth hormone on in vitro maturation of bovine oocytes is exerted through cumulus cells and not mediated by IGF-I. Molecular Reproduction and Development, 47, 175-180.

Jousan, F. D., \& Hansen, P. J. (2004). Insulin-like Growth Factor-I as a survival factor for the bovine preimplantation embryo exposed to heat shock. Biology of Reproduction, 71(5), 1665-1670.

Józwik, M., Józwik, M., Wolczynski, S., Józwik, M., \& Szamatowicz, M. (2001). Ammonia concentration in human preovulatoy ovarian follicles. European Journal of Obstetrics and Gynecology and Reproductive Biology, 94, 256-260.

Khadjeh, G. H. (2002). Concentration of serum enzymes in pregnant and non pregnant Iranian one-humped camels. Indian Journal of Animal Science, 72(5), 391-392.

Kim, J. Y., Kinoshita, M., Ohnishi, M., \& Fukui, Y. (2001). Lipid and fatty acid analysis of fresh and frozen-thawed immature and in vitro matured bovine oocytes. Reproduction, 122, 131-138.

Kruip, T. A. M., \& Dieleman, S. J. (1982). Macroscopic classification of bovine follicles and its validation by micromorpholigical and steroid biochemical procedures. Reproduction Nutrition Development, 22, 465-473.

Kruip, T. A. M., \& Kemp, B. (1999). Feeding and fertility in animal husbandry. Tijdschr Diergeneesk, 124(16), 462-467.

Leese, H. J., \& Lenton, E. A. (1990). Glucose and lactate in human follicular fluid: concentrations and interrelationships. Human Reproduction, 5, 915-919.

Leroy, J. L. M. R., Vanholder, T., Delanghe, J. R., Opsomer, G., Van Soom, A., Bols, P. E. J., \& de Kruif, A. (2004). Metabolite and ionic composition of follicular fluid from different-sized follicles and their relationship to serum concentrations in dairy cows. Animal Reproduction Science, 80, 201-211.

Leroy, J. L. M. R., Vanholder, T., Mateusen, B., Christophe, A., Opsomer, G., de Kruif, A., Genicot, G., \& Van Soom, A. (2005). Non-esterified fatty acids in follicular fluid of dairy cows and their effect on developmental capacity of bovine oocytes in vitro. Reproduction, 130(4), 485-495.

Leyens G, Verhaeghe B, Landtmeters M, Marchandise J, Knoops B, Donnay I. 2004. Peroxiredoxin 6 is up-regulated in bovine oocytes and cumulus cells during in vitro maturation: Role of intercellular communication. Biology of Reproduction, 71: 1646-1651.

McNatty, K. P., Smith, D. M., Makris, A., Osathanondh, R., \& Ryan, K. J. (1978). The microenvironment of the human antral follicle: interrelationships among the steroid levels in the antral fluid, the population of granulosa cells, and the status of the oocyte in vivo and in vitro. Journal Clinical Endocrinology \& Metabolism, 49, 851-860.

Mukasa-Mugerwa, E. (1981). Reproductive performance. In: ILCA Monograph, International Livestock Centre for Africa Edu. The Camel (Camelus dromedaries). A Bibliographical Review, 11-32. Addis Ababa.

O’Callaghan, D., \& Boland, M. P. (1999). Nutritional effects on ovulation. Animal Science, 68, 299-314. 
Okuda, Y., Okamura, H., Kanzaki, H., Takenaka, A., Morimoto, K., \& Nishimura, T. (1982). An ultrastructural study of capillary permeability of rabbit ovarian follicles using horseradish peroxidase as a tracer. Nippon Sanka Fujinka Gakkai Zasshi, 34, 181-186.

Prabhakar, S., Nanda, A. S., \& Ghuman, S. P. S. (1999). Sequential changes in some blood indices during peripartal period in buffaloes. Indian Veterinary Journal, 76, 1067-1070.

Rabiee, A. R., Lean, I. J., Gooden, J. M., \& Miller, B. G. (1999). Relationships among metabolites influencing ovarian function in the dairy cow. Journal Dairy Science, 82, 39-44.

Rabiee, A. R., Lean, I. J., Gooden, J. M., Miller, B. G., \& Scaramuzzi, R. J. (1997). An evaluation of transovarian uptake of metabolites using arterio-venous differences methods in dairy cattle. Animal Reproduction Science, 48, 9-25.

Richards, M. W., Spicer, L. J., \& Wettemann, R. P. (1995). Influence of Diet and Ambient-Temperature on Bovine Serum Insulin-Like Growth-Factor-I and Thyroxine - Relationships with Nonesterified Fatty-Acids, Glucose, Insulin, Luteinizing-Hormone and Progesterone. Animal Reproduction Science, 37(3-4), 267-279.

Saeed, A., Khan, I. A., \& Hussein, M. M. (2009). Change in biochemical profile of pregnant camels (Camelus dromedarius) at term. Comparative Clinical Pathology, 18, 139-143.

SAS Institute (2013). JMP Version 11 User's Guide. SAS Institute Inc., Cary, NC, USA.

Shehab-El-Deen, M. A. M. M., Leroy, J. L. M. R., Fadel, M. S., Saleh, S. Y. A., Maes, D., \& Van Soom, A. (2010). Biochemical changes in the follicular fluid of the dominant follicle of high producing dairy cows exposed to heat stress early post-partum. Animal Reproduction Science, 117, 189-200.

Sinclair, K. D., Kuran, M., Gebbie, F. E., Webb, R., \& McEvoy, T. G. (2000). Nitrogen metabolism and fertility in cattle: II. Development of oocytes recovered from heifers offered diets differing in their rate of nitrogen release in the rumen. Journal of Animal Science, 78, 2670-2680.

Singh, A. K., Prakash, C., Rohit, K., Karunakaran, M., Santra, A., \& Subrata K. D. (2017). In vitro development of cattle embryos using triiodothyronine as a media supplement. International Journal of Advanced Biotechnology Research, 7: 25-31.

Skidmore, J. A., Billah, M., \& Allen, W. R. (1995). The ovarian follicular wave pattern in the mated and non-mated dromedary camel (Camelus dromedarius). Journal of Reproduction Fertility (Suppl), 49, 545-548.

Skidmore, J. A., Billah, M., \& Allen, W. R. (1996). The ovarian follicular wave pattern and induction of ovulation in the mated and non-mated one - humped camel (Camelus dromedarius). Journal of Reproduction and Fertility, 106, 185-192.

Wehrman, M.E., Welsh, T.H., Williams, G.L. (1991): Diet-induced hyperlipidemia in cattle modifies the intrafollicular cholesterol environment, modulates ovarian follicular dynamics, and hastens the onset of postpartum luteal activity. Biology of Reproduction, 49, 514-522.

Wise, T. (1987). Biochemical analysis of bovine follicular fluid: albumin, total protein, lysosomal enzymes, ions, steroids and ascorbic acid content in relation to follicular size, rank, atresia classification and day of estrous cycle. Journal of Animal Science, 64, 1153-1169.

\section{Copyrights}

Copyright for this article is retained by the author(s), with first publication rights granted to the journal.

This is an open-access article distributed under the terms and conditions of the Creative Commons Attribution license (http://creativecommons.org/licenses/by/4.0/). 